\title{
Branding a Revolution: Revolutions as Brands and Their Implications for Modern Marketing
}

\author{
Rasha H. A. Mostafa ${ }^{1}$, Omar Ramzy ${ }^{2} \&$ Omar H. Eldahan ${ }^{2}$ \\ ${ }^{1}$ Faculty of Commerce, Ain-Shams University, Cairo, Egypt \\ ${ }^{2}$ Faculty of Business and Economics, Heliopolis University for Sustainable Development, Egypt \\ Correspondence: Omar H. Eldahan, Faculty of Business and Economics, Heliopolis University for Sustainable \\ Development, El-Horreya, Egypt. Tel: 20-11-5050-2076. E-mail: omar.eldahan@hu.edu.eg
}

Received: February 25, 2017 Accepted: April 5, 2017 Online Published: May 29, 2017

doi:10.5539/ijms.v9n3p1 URL: http://doi.org/10.5539/ijms.v9n3p1

\begin{abstract}
Modern marketing recognizes that many different concepts can fall under the view of marketing, revolutions are no different. This research analyses, through a qualitative review of the literature, if and how revolutions can be considered as brands that can be communicated to its target customers (revolutionaries). Based on the analysis results, foundational premises are established and a theoretical model is developed to be further examined in future research. The originality of the paper is illustrated via focusing on branding revolutions, a concept that is rarely, if ever, underscored in the marketing literature. Furthermore, it sets up the foundation for future research in this direction.
\end{abstract}

Keywords: branding, Egyptian revolution, social networks, social media

\section{Introduction}

Revolutions have occurred throughout human history repeatedly, and are considered widely as acts of revolt to change socio-cultural and political systems of nations. Causes and consequences of revolutions have been extensively studied by scholars from the fields of sociology, psychology, political science, and economics. However, in examining scholarly thoughts on revolutions, marketing and branding perspectives were never explored nor examined. This opens up many interesting concepts. For example, this paper approaches marketing on a macro-level (as the revolution of a country-scale, and even region-scale, event). However, in this context while the approach is towards macro-marketing, the application is on a different scale. In other words, how can a revolution (a macro event) impact the branding in the eyes of people around the world (both a macro and micro perspectives)?

In this regards, the question being asked is far too broad to be answered properly in one research paper. However, it is a query that is rarely asked and almost never (if ever) answered. Thus, the current research will take an instance of a revolution and explore its meanings with regard to branding. The example that will be taken is the Egyptian 25th of January, 2011 revolution. Furthermore, the researchers will explore one of the most prominent aspects of the revolution, namely: social media and its influences. Via looking at social media from a macro-marketing lens, the researchers can realize how it influences major societal changes, and how the later influence the adoption and use of social media.

Ultimately, the purpose of this paper is three-fold; first, to understand the nature of revolutions in shaping national brand; second, to explore how consumers perceive products and services attached to a revolution by investigating their notion and position towards social media; and finally, to create a groundwork for future research that examines the impact revolutions have on the marketing scene within a country on a micro and macro levels.

\section{Literature Review}

\subsection{The Arab Spring}

On January 25th, 2011 the political environment of Egypt changed when Egyptians toppled an authoritarian regime that had ruled the country for thirty years. Known as "The Facebook Revolution" (Moalla, 2013), it was mainly charged by the Egyptian youth (aka the Facebook generation), and had a profound impact on Egypt on 
every imaginable level. Whatever was to come, one thing was certain, Egypt would never be the same again.

It all started on December 17th, 2011 when a twenty six year old Tunisian street vendor called Mohamed Bouazizi ended his life in protest of his treatment at the hands of the Tunisian police authority (Noor, 2011). Prior to this incident, the police had confiscated his cart and insulted him in public. Bouazizi did not even have enough money to pay the bribe required in order to have his cart returned; the result was the tragic suicide that captivated the world. His death soon became an analogy of Arab nations perishing while the general populace stood by, helpless to do anything. However, this time they did do something; this tragedy was followed by protests in Bouazizi's rural hometown that quickly spread to other areas and, ultimately, the Tunisian capital.

Bouazizi's story was rapidly shared in Facebook and other online communities where his self-immolation was the beginning of a chain of events that led to the ouster of Tunisia's president, Ben Ali's. On January 14th, 2011 Ben Ali and his family fled to Saudi Arabia (Moalla, 2013).

As for Egypt, on January 24th there was a strong rumour across Egypt that there would be a revolution on the following day. At the time this rumour sounded odd to experts across the world since revolution often did not rely on specific dates. However, online communities were not on-hand throughout historical revolutions. According to Ghannam (2011) five million Egyptians were active members on Facebook on January $25^{\text {th }}, 2011$. Inspired by the successful revolution in Tunisia, online Egyptian bloggers started organizing mass protest for that day, which coincided with the Egyptian Police Force Day. Everyone was shocked when thousands of protesters gathered in Tahrir square to protest corruption, poverty, unemployment, inflation, and autocratic governance of Mubarak who has ruled the country since 1981 (Parks, 2011).

On January 28th, reacting out of the understanding that the revolution was being driven by the internet, the Egyptian government completely blocked the internet, cell phones, and Blackberry messenger (Kanalley, 2011), which led to the beginning of an interesting phenomenon. While Facebook and Twitter and other social media networks did not outright support the revolution, these companies (and, more specifically, these brands) were thrust to forefront of the revolution as the main tool for organizing and spreading information, and became synonymous with the Arab spring. Even Google was not able to escape this labelling as one of its executives, Wael Ghoneim, soon became a face for the Egyptian Revolution.

Same day, January 28th', the military took over the security of the streets, thus filling a gap left by the police who were ordered to stop their activities. This step was very welcomed by the protestors since the Egyptian military is often seen as a national institute that stands by the Egyptian people. Thousands of protestors remained in camp in Tahrir square calling for Mubarak to step down. As a result, several concessions were announced as follows:

- Changing the ministerial cabinet

- Appointing a vice-president for the first time in three decades

- Egypt's new vice-president promises dialogue with opposition parties

- Mubarak announces in a televised address that he will not run for re-election

- Mubarak promises reforms to the constitution, particularly Article 76, which makes it virtually impossible for independent candidates to run for office

- Internet service was partially restored across the country

- Resignation of key leaders of Egypt's ruling National Democratic Party

- Egypt's government approves a 15\% raise in salaries and pensions

After three continuous weeks of strikes, Mubarak resigned as a president and hands over power to the military (Aljazeera, 2011; MSNBC, 2011).

\subsection{Digital Media Landscape}

Digital media has contributed to the advancement of civil society and the promotion of accountability (Balkin, 2004). In Egypt the government has taken positive steps to encourage internet usage especially to switch the dialup connection to the faster Asymmetric Digital Subscriber Line (ADSL) connectivity. About $61 \%$ of the Egyptian households were connected to the internet at the time of the Egyptian revolution which was a massive increase on years prior (MCIT, 2008, 2012).

Studies of the Arab and Iranian blogosphere, conducted by Harvard University in 2008 and 2009 provide a demographic profile of internet users. Arab and Iranian bloggers were overwhelmingly young with the vast majority under the age of 35 (Etling, Kelly, Faris, \& Palfrey, 2009). 


\subsection{Digital Media as a Social Networking Platform}

Social media and online communities are more about experiences than conventional websites. In fact, "social media is personal, it is a conversation" (Anonymous, 2012). These experiences start when customers are attracted, engaged, retained, learned, and related (Albert \& Sanders, 2003). The researchers cannot assume that online social networks and online media are replacements of traditional media. On the contrary, both venues go hand in hand. Egyptian youth used Facebook and other online social media to share material and to reach each other. At the same time, they communicated verbally during protests via cell phones and other physical handy boards to express their opinions. The internet and online social media have the unique advantages of reach, richness, and engagement.

Marketers should deal with online and offline media as one mechanism for communication. Companies are interested in using online social media to reach online customers and social networks are becoming more and more important to companies (Chaputual \& Majawa, 2013). Usually the challenge faced is how to be effective in building brands and getting connected with your online audience.

\subsection{Place Branding}

A superior product offered to empowered customers in a condensed or a matured market is not enough to guarantee marketing success (Keller \& Richey, 2006). The current environment is indicating that building strong brands and corporate brands are effective tools to customers' minds. Brand personalities are the traits that reflect brands unique characteristics. Similar to human beings, brands are like living objects, talking; socializing; interacting; coping with other brands; dealing with the surroundings and communicating and interacting with people. However, corporate branding is a wider concept since some companies usually carry many brands and have many employees who reflect the corporate personality.

A nation as a brand is not a new concept. Previously, marketers adopted place marketing techniques to attract tourists, generate fund raising pools, or fans in national sports events. However, a revolution as a brand (as a concept in the marketing literature) is not so well developed. Consider that, according to (Kashi, 2013), a main component that is perceived of a brand is that of "emotional value"; this component is what drives the idea that a brand can be made of the revolution due to the emotional impact that has amongst Egyptians (and even non-Egyptians). As such, we can begin to understand the impact of the revolution on brands from the perspectives of loyalty, image, and value as displayed in (Tiwari, 2010). In this paper, the researchers not only want to discuss the impact of using the Egyptian revolution as a brand, but also how it fits into network communities and social networks. Thus, we need to understand their nature in order to develop a framework in which a significant opportunity of branding can be taken advantage of - specifically "branding revloutions".

\section{Methodology}

This research falls under Positive/Profit/Macro-marketing research as detailed in (Hunt, 2010, p. 10). To the researchers' knowledge, there are almost no studies in the literature directly connecting revolutions with brands. The existing research is exploratory in nature where secondary data will be analysed in order to conceptualize a framework for studying the impact of revolutions on branding. The revolution under study is the Egyptian $25^{\text {th }}$ of January 2011 one, and the industry which will be looked at in terms of a changing brand is social media. In some ways, this research can fall under the paradigm of Hermeneutics, defined as "the art of interpretation" (Lessem $\&$ Schieffer, 2010, p. 133). Thus, the researchers will interpret the Egyptian revolution from several standpoints benefiting from hindsight, as well as marketing perspective on the opportunities that arose.

The paper will first focus on establishing that revolutions can be perceived as brands. Then, it will revolve around making Foundational Premises (FPs) grounded on the researchers' qualitative study such as in (El-Bassiouny, 2014). FPs will be numbered based on their association, where FP1.x will reflect the social media and FP2.x will reflect the revolutions. Finally, a model will be developed connecting the two FP's, thus providing a conceptual framework to be empirically studied and reviewed in future researches.

\section{Analysis}

\subsection{Branding the Revolution}

In this section the revolution will be analysed as a brand. One of the essential tasks played by brands is related to name, term, sign, symbol or design, or a combination of these (Erdem \& Swait, 1998). These attributes identify goods and services, as well as differentiate sellers from one another (Kotler, 1997, p. 443). We assume that these elements surrounded both revolutions in Egypt and Tunisia. We took the Egyptian case as a clear application of our thoughts. 
Considering the revolutions and how they are perceived, it is evident that the issue has become very contentious. While many people have come to view the revolution in many different ways, one thing is very obvious; just mentioning the revolution brings out strong emotions and reactions from Egyptians and even some non-Egyptians.

During the revolution, the Egyptian youth began promoting it with regards to freedom, democracy, human rights, corruption free environment, and better future. This promotion took place, of course, through modern communication devices using social media. The revolutionaries decided to turn the revolution in a kind of brand by associating it with these concepts. Whether or not that was the intention, the result is obvious; the 25th of January Revolution has become a brand synonymous with Egypt. Nonetheless, just as with the case with any brands, it can have either positive or negative connotations.

The researchers believe that success was due to nation rebranding themes that were displayed in the social media. Basically, this was a kind of new product launch, with a concept (the revolution) being offered or promoted to the Egyptian people and the world. The competition here was the state media and propaganda telling the citizens otherwise. Victory went to the side that branded and marketed their "product" better. This is because the youth in virtual communities rely on peer to peer wisdom in new idea generation (Wu \& Fang, 2010); this is opposed to Mubarak's regime focusing more on experts opinions.

Considering the meanings of brands such as those reflected in (Tybout \& Carpenter, 2001, pp. 76-77), it becomes apparent that revolutions have brands. It is because people apply meaning and value to these revolutions (whether positive or negative) that we can consider them as brands that can be used in a marketing context.

The next section will detail what aspects of revolutions are considered in a branding context as well as the connection between these brands and social media.

\subsection{Network Communities}

Hamman (1998) defines communities as: "(1) a group of people who (2) share social interaction and (3) some common ties between themselves and the other members of the group and who, (4) share an area for at least some of the time". Sharing knowledge expertise and ideas of the individuals and groups with continuous interactions are considered the real value of online communities (Kodama, 1999). Online communities are composed of groups that have common purposes and a wide variety of member roles with members independently solving their own conflicts (Pallof \& Pratt, 1999). Social communities are excellent platforms to facilitate the sharing of similar values, beliefs, and interests (Hallahan, 2008).

The policies of online communities entail issues such as registration and membership, security, privacy, and freedom of speech (Sillence \& Barber, 2004). Brinkerhoff (2005) argued that the internet boosts liberal principles such as freedom of speech and individualism. In addition it has the potential to revolutionize political activities far better than broadcasted and printed media (Ferdinand, 2000). The context of online communities is built on transaction oriented, interest oriented, relationship oriented, and fantasy oriented (Spaulding, 2010). Essential for online community success is the attitude of contribution, spreading resources, critical mass, and aligning the community activities with external environmental needs.

Successful online communities either generate positive cash flows or achieve brand recognition (Kerin \& Sethuraman, 1998). Social concepts and trust compose the foundations of successful online communities. These concepts are witnessed by members devoting time or other resources in exchange for benefits obtained. Interest oriented communities are very sensitive to inefficient or improper use of their resources; if this happens trust is easily broken and reputation destroyed. Benefits include affiliation, knowledge, and social relationships. Because all communities are based on social interactions, then trust plays a significant role in sustaining community members (Smith \& Kollock, 1999). If trust is broken, members will automatically leave the community.

In the business world, online community members always want to know how their contribution in the community impacts the product design and development. If the product under consideration is of interest to community members, then they often want to be insiders in its development process. They wish for being the first to know what the product will look like. When members feel that their contribution creates an action then they sense being real insiders in the community (Porter \& Donthu, 2008).

This, of course, directly relates to User Generated Content (UGC). According to the Organization for Economic Cooperation and Development (OECD), online communities must fulfil three requirements as to be considered UGCs. First, they need to be published in a publicly accessible website or in social community accessible to certain segment. Second, it needs to be creative, as being not traditional. Third, it should not be created within a professional or routine context. All three UGC requirements completely fit with the Egyptian Facebook 
revolution.

In branded online communities, members interact together based on their brand knowledge and may refer to group members to solve product related issues without referring to the customer service helpdesk. Information exchange and interactions are spread out geographically with no space limitations. This wide scope of interactions and relationships results in diversified useful knowledge based on peer's content, which is extremely resourceful (Wu \& Fang, 2010). New ideas about product development could be enhanced easily in these communities. In application to the Egyptian revolution, the idea of better future in the course of freedom was clearly introduced out of user generated content. Democratization of innovation, a term used in previous literature to describe users' innovative ideas based on interactions in online communities was deeply carried out by Egyptian youth in online communities. However, the literature seldom handled democratization process to launch a democratic idea as a final product which relates to a nation as a new brand.

Hence, the following Foundation Premises (FP) can be developed:

FP 1.1: Social Media promote Freedom of Expression

FP 1.2: Social Media focus on User Generated Content

\subsection{Network Communities in Egypt and the Arab World}

While it has long been said that customers (or people for this particular matter) are more empowered today than ever before (Berthon, Pitt, McCarthy, \& Kates, 2007). It is evident that when people are engaged together in an interactive platform they get more involved. In this specific case Egyptians used online communities to sell clear and genuine ideas to other members, particularly through network communities (or social media, as it were). These ideas were generated by users known as user generated content (UGC). This was fed due to the fact that Middle-Eastern print and broadcasted press have always been subject to government controls and restrictions (Shirazi, 2008). This resulted in the state news becoming an unreliable source of news making networked communication being the de-facto source of information. This connection between Egyptians, most of whom has never even met each other before, suddenly relying on each other to provide accurate interpretations of the happenings in the country.

Furthermore, Facebook is being used extensively in Arab countries to promote freedom; democracy and human rights (Kim, Jeong, \& Lee, 2010). Egyptian youth through online interactions achieved what several activists could not attain for decades. It is assumed that the basic idea of any collaborative project is maximizing the outcome that cannot be achieved by one actor (Kaplan \& Haenlein, 2010). The value of online communities is not limited to texting messages but more into democratic conversations (Levine, Locke, Searls, \& Weinberger, 2000, p. 87) and creative content. Accordingly, the following Foundation Premises (FP) can be established:

FP 1.3: Social Media is associated with Reliable Content

FP 1.4: Social Media is associated with Trust

Thus, all of this created something very interesting; these events resulted in the establishment of a great deal of trust among these differing communities. This means that a whole new concept is being born, connecting social networks and revolutions together which is an integral part of this new brand building process.

\subsection{The Facets of the Revolutions}

As was previously discussed, the revolution was brought on by many factors. Among the most important was a high power distance, high poverty levels, limited freedoms, injustices, social instability, and so on. Realising as how the paper focuses on the aspects of revolution branding, we can consider a few different ideas emerging. For example, rarely have we seen a revolution be characterized or branded by fighting poverty; instead they usually focus on the issues of justice and freedom, or, in other words, democracy.

The Egyptian youth generated content through virtual communities which is the natural process of democratizing a new innovation, and the final output was to launch democracy as a new product in Egypt. Democracy and freedom are products marketed by the Egyptian youth with high incentives to solve a major problem by offering creative solution that all Egyptians appreciate. Exactly like the product development process where users depend on their online interactions to generate relevant product ideas (Franke \& Shah, 2003; Tietz, Morrison, \& Herstatt, 2005). Egyptians interacted together based on their common interests and needs and counted on these in the revolution process.

We argue that democratizing the innovation process applies purely to intangible ideas as well as the nation rebranding that happened in Egypt. In our country, Egypt, virtual communities and information communication technology enhanced the democratic process in a timely manner (Morrisett, 2003). 
Egyptian youth proved Balkin (2004) right that the digital revolution brought freedom of expressions and extended cultural participation and interactions. As online communities were the platforms used in Egypt for cultural participation and the production of new culture and ideas. The internet and many other digital devices empowered citizens to engage in the democratic sphere by practicing e-democracy (Clift, 2003; Macintosh \& Coleman, 2003; McCullagh, 2003; Morrisett, 2003). Egyptian youth followed the digital path which allowed more political participation, and ultimately the creation of new ideas related to human rights and democracy. Based on this and from the previous literature review, the following Foundation Premises can be underscored:

FP 2.1: Revolutions are Freedom Oriented

FP 2.2: Revolutions seek Unbiased News

FP 2.3: Revolutions start when they have Grass-Roots Support

FP 2.4: Revolutions are based on Community Trust and Integrity

\subsection{The Theoretical Model}

Based on the above mentioned Foundation Premises, the researchers establish a model connecting the revolution with Social Media. As highlighted here under in Table 1, the different FPs of Social Media and the revolutions can be associated with each other.

Table 1. Connecting the associated foundational premises

\begin{tabular}{ll}
\hline Foundational Premises on Social Media & Foundational Premises on Revolutions \\
\hline FP 1.1: Social Media promote Freedom of Expression & FP 2.1: Revolutions are Freedom Oriented \\
FP 1.2: Social Media focus on User Generated Content & FP 2.3: Revolutions start when they have Grass-Roots Support \\
FP 1.3: Social Media is associated with Reliable Content & FP 2.2: Revolutions seek Unbiased News \\
FP 1.4: Social Media is associated with Trust & FP 2.4: Revolutions are based on Community Trust and integrity \\
\hline
\end{tabular}

All these aspects are brought together as a way of perceiving the branding of both social media and revolutions in terms of brand personality and brand image. The Theoretical Model is shown in Figure 1.

\section{Conclusion and Future Research}

The implications modern revolutions have in shaping the world become crystal clear. Revolutions can have both branding and marketing insinuations that go two-ways; the first is that the marketer can begin to understand consumer's views of their products and services depending on their connection to the revolutions. The second way is that this understanding of branding can help those people suffering from oppression to recognize the key elements of a successful revolution. Considering that the propaganda can play a fundamental role in branding the state and a corrupt regime, hence it must be faced with marketing and branding efforts of those who wish to bring about change.

The Egyptian revolution provides a perfect perspective into the process of branding the revolution. Social media and the internet in general truly facilitated this matter and allowed for a strong opposition to state media and propaganda helping to realize success in the revolution.

From a marketing perspective, the researchers looked at how companies and brands that are related in the consumers' cognitive maps can be affected by each other using a qualitative study of the literature and of the news of the revolution. The results emphasized that the revolutions' brands can be correlated, but only if they share common characteristics, such as with social media.

More in-depth, empirical studies are needed in the future in order to prove the viability of the theoretical model. Furthermore, additional research is required to find ways of measuring the individual aspects of the characteristics of the revolution, as well as add the ones that apply and remove those that do not. This study is considered, hopefully, only the beginning in understanding marketing and branding impact in a revolutionary setting. 


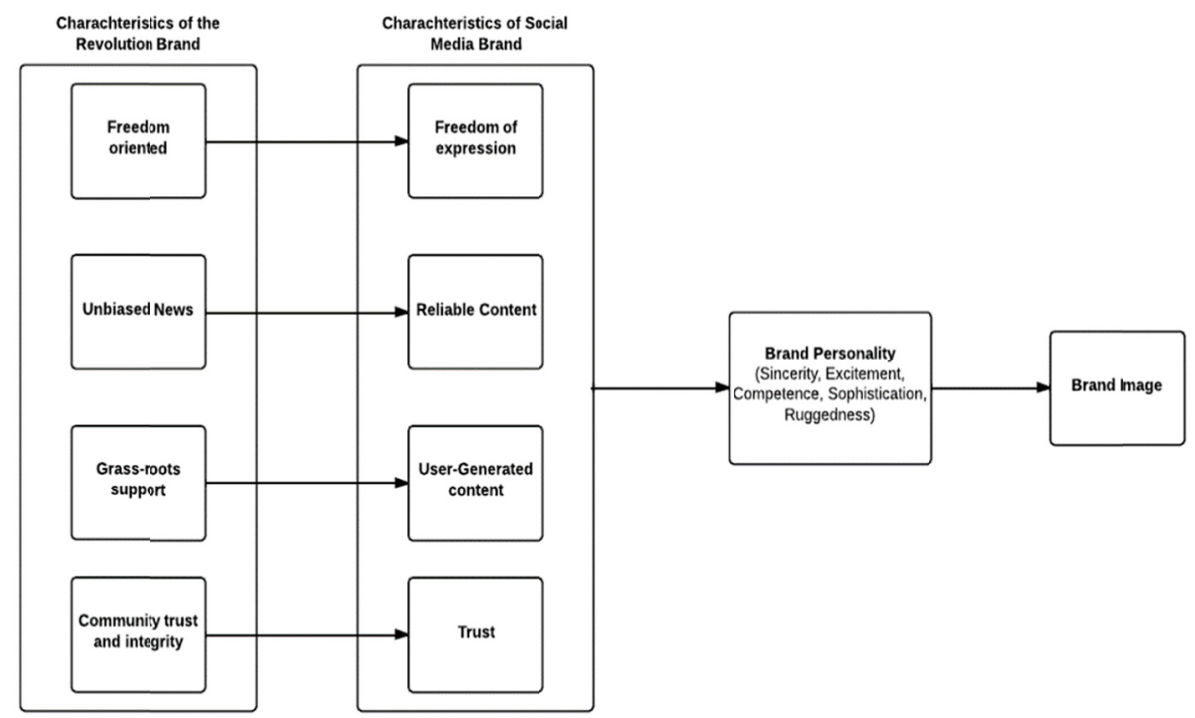

Figure 1. Framework for branding revolutions in relation to social media

\section{References}

Albert, T., \& Sanders, W. (2003). E-Business Marketing. Upper Saddle River, NJ: Prentice Hall.

Aljazeera. (2011). Timeline: Egypt's Revolution. Aljazeera. Retrieved from http://www.aljazeera.com/news/middleeast/2011/01/201112515334871490.html

Anonymous. (2012). New media needs new marketing: Social networking challenges traditional methods. Strategic Direction, 28(6), 24-27. http://dx.doi.org/10.1108/02580541211224085

Balkin, J. M. (2004). Digital speech and demcratic culture: A theory of freedom of expression for the information society. New York University Law Review, 79(1), 1-55. Retrieved from http://digitalcommons.law.yale.edu/fss_papers/240

Berthon, P. R., Pitt, L. F., McCarthy, I., \& Kates, S. M. (2007). When customers get clever: Managerial approaches to dealing with creative consumers. Business Horizons, 50(1), 39-47. http://dx.doi.org/10.1016/j.bushor.2006.05.005

Brinkerhoff, J. M. (2005). Digital diasporas and dovernance in semi-authoritarian states: the case of the Egyptian copts. Public Administration and Development, 25(3), 193-204. https://doi.org/10.1002/pad.364

Chaputual, A. H., \& Majawa, F. P. (2013). Use of social network sites by mass media organisations in Malawi. Aslib Proceedings: New Information Perspectives, 65(5), 534-557. http://dx.doi.org/10.1108/AP-06-2012-0055

Clift, S. (2003). E-democracy, e-governance and public net-work. Publicus.Net. Retrieved from http://www.publicus.net/articles/edempublicnetwork.html

El-Bassiouny, N. (2014). The one-billion-plus marginalization: Toward a scholarly understanding of Islamic consumers. Journal of Business Research, 67(2), 42-49. http://dx.doi.org/10.1016/j.jbusres.2013.03.010

Erdem, T., \& Swait, J. (1998). Brand equity as a signaling phenomenon. Journal of Consumer Psychology, 7(2), 131-157. http://dx.doi.org/10.1207/s15327663jcp0702_02

Etling, B., Kelly, J., Faris, R., \& Palfrey, J. (2009). Mapping the Arabic blogosphere: Politics, culture, and dissent. Berkman Center Research Publication. Retrieved from http://cyber.law.harvard.edu/sites/cyber.law.harvard.edu/files/Mapping_the_Arabic_Blogosphere_0.pdf

Ferdinand, P. (2000). The Internet, democracy and democratization. Democritization, 7(1), 1-17. http://dx.doi.org/10.1080/13510340008403642 
Franke, N., \& Shah, S. (2003). How communities support innovative activities: An exploration of assistance and sharing among end-users. Research Policy, 32(1), 157-178. https://doi.org/10.1016/S0048-7333(02)00006-9

Ghannam, J. (2011). Social media in the Arab world: Leading up to the uprisings of 2011. Retrieved from http://cima.ned.org/sites/default/files/CIMA-Arab_Social_Media-Report - 10-25-11.pdf

Hallahan, K. (2008). Organizational-public relationships in cyberspace. In T. Hansen-Horn \& B. Neff (Eds.), Public relations: from theory to practice (pp. 47-73). Boston: Allyn \& Bacon.

Hamman, R. (1998). The online/offline dichotomy: debunking some myths about AOL users and effects of their being online upon offline friendships and offline community. University of Liverpool. Retrieved from http://www.cybersoc.com/mphil.html

Hunt, S. D. (2010). Marketing theory: foundations, controversy, strategy, resource-advantage theory. M. E. Sharpe.

Kanalley, C. (2011). Egypt's internet shut down, according to reports. The huffington post. Retrieved from http://www.huffingtonpost.com/2011/01/27/egypt-internet-goes-down-_n_815156.html

Kaplan, A., \& Haenlein, M. (2010). Users of the world, unite! The challenges and opportunities of social media. Business Horizons, 53(1), 59-68. http://dx.doi.org/10.1016/j.bushor.2009.09.003

Kashi, A. N. (2013). Exploring consumer purchase behaviour: foreign versus local brands. Global Business Review, 14(4), 587-600. https://doi.org/10.1177/0972150913501600

Keller, K. L., \& Richey, K. (2006). The importance of corporate brand personality traits to a successful 21st century Business. Brand Management, 14(1/2), 74-81. https://doi.org/10.1057/palgrave.bm.2550055

Kenner, D. (2011). Pharaoh's end. Foreign policies. Retrieved from http://www.foreignpolicy.com/articles/2011/01/28/pharaohs_end

Kerin, R. A., \& Sethuraman, R. (1998). Exploring the brand value-shareholder value nexus for consumer goods companies. Journal of the Academy of Marketing Science, 26(4), 260-273. https://doi.org/10.1177/0092070398264001

Kim, W., Jeong, O. R., \& Lee, S. W. (2010). On social web sites. Information Systems, 35(2), 215-236. http://dx.doi.org/10.1016/j.is.2009.08.003

Kodama, M. (1999). Customer value creation through community-based information networks. International Journal of Information Management, 19(6), 495-508. http://dx.doi.org/10.1016/S0268-4012(99)00045-6

Kotler, P. (1997). Marketing management (7th ed.). Pearson.

Lessem, R., \& Schieffer, A. (2010). Integral research and innovation. Gower.

Levine, R., Locke, C., Searls, D., \& Weinberger, D. (2000). The cluetrain manifesto: the end of business as usual. 2000. Cambridge: Perseus Publishing.

Macintosh, A., \& Coleman, S. (2003). Promise and problems of e-democracy: challenges of online citizen engagement. Organisation for Economic Co-operation and Development.

McCullagh, K. (2003). E-democracy: potential for political revolution? International Journal of Law and Information Technology, 11(2), 149-161. https://doi.org/10.1093/ijlit/11.2.149

MCIT. (2008). The future of the internet economy in Egypt: Version I. Arab Repuclic of Egypt Ministry of Communications and Information Technology.

MCIT. (2012). ICT indicators in brief. Ministry of Communications and Information Technology.

Moalla, A. (2013). Tunisia in the aftermath of the revolution: insights into the use of humor on Facebook to create social bonds and develop relational identity. Sage Open, (3), 1-7. https://doi.org/10.1177/2158244013504765

Morrisett, L. (2003). Technologies of freedom? In H. Jenkins \& D. Thorburn (Eds.), Democracy and New Media (pp. 21-31). Cambridge: MIT Press.

MSNBC. (2011). Concessions in Egypt before March of a million. NBC News. Retrieved from http://www.nbcnews.com/id/41347609/ns/world_news-mideast_n_africa/t/concessions-egypt-march-millio n/\#.U4g21_mSykA

Noor, N. (2011). Tunisia: the revolution that started it all. International Affairs Review. Retrieved from http://www.iar-gwu.org/node/257 
Pallof, R. M., \& Pratt, K. (1999). Building learning communities in cyberspace. San Francisco: Jossey-Bass Publishers.

Parks, C. (2011). What's going on in Egypt? He Huffington Post. Retrieved from http://www.huffingtonpost.com/2011/01/28/whats-going-on-in-egypt_n_815734.html

Porter, C. E., \& Donthu, N. (2008). Cultivating trust and harvesting value in virtual communities. Management Science, 54(1), 113-128. http://dx.doi.org/10.1287/mnsc.1070.0765

Shirazi, F. (2008). The contribution of ICT to freedom and democracy: an empirical analysis of archival data on the Middle East. The Electronic Journal of Information Systems, 35(6), 1-24.

Sillence, E., \& Barber, C. (2004). Integrated digital communities: combining web-based interaction with text messaging to develop a system for encouraging group communication and competition. Interacting with Computers, 16(1), 93-113. http://dx.doi.org/10.1016/j.intcom.2003.11.007

Smith, M. A., \& Kollock, P. (1999). Communications in cyberspace. Abingdon-on-Thames: Routledge. https://doi.org/10.5117/9789056290818

Spaulding, T. (2010). How can virtual communities create value for business? Electronic Commerce Research and Applications, 9(1), 38-49. http://dx.doi.org/10.1016/j.elerap.2009.07.004

Tietz, R., Morrison, P. D., \& Herstatt, C. (2005). The process of user-innovation: a case study in a consumer goods setting. International Journal of Product Development, 2(4), 321-338. http://dx.doi.org/10.1504/IJPD.2005.008005

Tiwari, M. K. (2010). Separation of brand equity and brand value. Global Business Review, 11(3), 421-434. https://doi.org/10.1177/097215091001100307

Tybout, A. M., \& Carpenter, G. S. (2001). Creating and managing brands. In D. Iacobucci (Ed.), Kellog on Marketing (pp. 74-102). New York: John Wiley.

Wu, S. C., \& Fang, W. (2010). The effect of consumer-to-consumer interactions on idea generation in virtual $\begin{array}{llll}\text { brand } \quad \text { community } & \text { Technovation, 30(11), }\end{array}$ http://dx.doi.org/10.1016/j.technovation.2010.07.005

\section{Copyrights}

Copyright for this article is retained by the author, with first publication rights granted to the journal.

This is an open-access article distributed under the terms and conditions of the Creative Commons Attribution license (http://creativecommons.org/licenses/by/4.0/). 